\title{
Powiązania handlowe wewnątrz makroregionu Morza Bałtyckiego - w kierunku integracji regionalnej Trade linkages within the Baltic Sea region - towards regional
integration
}

\author{
Barbara Szejgiec-Kolenda (iD) Patryk Duma (it) \\ Instytut Geografii i Przestrzennego Zagospodarowania im. S. Leszczyckiego PAN \\ ul. Twarda 51/55, 00-818 Warszawa \\ b.szejgiec@twarda.pan.pl•p.duma@twarda.pan.pl
}

\begin{abstract}
Zarys treści. W artykule handel zagraniczny wykorzystano jako wskaźnik spójności i powiązań wewnątrzregionalnych. Pozwoliło to na przeanalizowanie przepływów towarowych i usługowych pomiędzy krajami należącymi do makroregionu Morza Bałtyckiego pod kątem ich skali i intensywności. W kontekście hipotezy o pogłębianiu integracji gospodarczej wewnątrz struktur unijnych w obrębie makroregionu, autorzy potwierdzili, że choć w okresie objętym analizą nastąpiły zmiany ilościowe i jakościowe powiązań handlowych, to procesy te przebiegały w sposób nierównomierny. Mimo silnych relacji gospodarczych nadal utrzymują się historyczne podziały wewnętrzne.
\end{abstract}

Słowa kluczowe: region Morza Bałtyckiego, strategie makroregionalne, handel zagraniczny towarami, międzynarodowy handel usługami, przepływy towarów i usług.

Keywords: Baltic Sea region, macroregional strategies, foreign trade in goods, international trade in services, flows of goods and services.

\section{Wstęp}

Do podstawowych uwarunkowań procesów rozwojowych w obecnej Europie, według Koneckiej-Szydłowskiej et al. (2019) należą: transformacja, integracja gospodarcza, globalizacja i postmodernizm. Z jednej strony Europa różnicuje się pod względem rozwoju społeczno-gospodarczego (odmienne procesy rozwojowe), a z drugiej - mamy do czynienia z unifikacją różnych przejawów życia społeczno-gospodarczo-politycznego. We współczesne trendy wpisuje się problematyka handlu międzynarodowego jako jeden z najważniejszych fundamentów bieżących procesów internacjonalizacji i globalizacji, jak również siła napędowa rozwoju gospodarczego. A handel jest dobrym wskaźnikiem spójności i powiązań wewnątrz- i międzyregionalnych, ponieważ pokazuje przepływy między krajami (BT2050, 2019; por. przestrzenie przepływów - Castells, 1998).

Z kolei jak twierdzi Faludi (2019, s. 42), w obecnych czasach, w świecie bardziej połączonym niż kiedykolwiek, jest także miejsce na terytorializm i współpracę w stawaniu wobec globalnych wyzwań: „(...) nie ma innego wyjścia, jak zmierzyć się ze światem takim, jakim jest: zrastać się razem, nie w jedną pełną całość, ale stając się złożoną wiązką" 
(tłum. aut.). Takie podejście znajduje swoje odzwierciedlenie w ostatnich trendach polityki unijnej polegającej na popularyzacji idei strategii makroregionalnych. Choć w opinii Steada (2011) unijne strategie makroregionalne w zasadzie nie oznaczają jakiejkolwiek fundamentalnej zmiany w polityce, to są przejawem pewnego rodzaju przeskalowania (rescaling) zwracającego większą uwagę nie na poszczególne jednostki przestrzenne, a na łączące je relacje. Odpowiadają również za odejście od ściśle sformalizowanych kierunków w zarządzaniu terytorialnym ku tzw. soft spaces („miękkie” zarządzanie bez wprowadzania dodatkowych struktur instytucjonalnych).

Obecnie wiele dyskusji i działań w Unii Europejskiej poświęconych jest kreowaniu i wzmacnianiu więzi ponadregionalnych. I tak w przypadku regionu Morza Bałtyckiego $(\mathrm{BSR})^{1}$ takie problemy podejmuje m.in. komitet VASAB (Vision and Strategies around the Baltic Sea - Wizje i Strategie wokół Morza Bałtyckiego) $)^{2}$ który zwraca uwagę na fakt, że odnowione historyczne więzi wokół Bałtyku pobudziły wymianę handlową i zwiększyły intensywność współpracy bałtyckiej, wskazując przy tym, że północno-zachodnia Rosja powinna być lepiej zintegrowana z regionem (VASAB, 2010). W Strategii UE dla regionu Morza Bałtyckiego (KE, 2009) mówi się, że „BSR jest zjednoczony poprzez morze”, jak też podkreśla, że jest wyraźnie podzielony.

$\mathrm{Na}$ tle aktualnych strategii makroregionalnych BSR stanowi unikalną jednostkę makroregionalną na poziomie UE o silnych historycznych podstawach współpracy, tym samym bałtycki model współpracy (por. Słomczyńska, 2014; Palmowski, 2017) to doskonałe pole badawcze dla analiz powiązań gospodarczych i konkurencji w regionie Morza Bałtyckiego. Po rozszerzeniu UE w 2004 r. Bałtyk stał się morzem wewnętrznym UE, a przyjęta w 2009 r. Strategia UE dla regionu Morza Bałtyckiego przyczyniła się do wzmocnienia instytucjonalnych aspektów współpracy pomiędzy krajami regionu. Najważniejsze polskie badania nad integracją Europy Bałtyckiej zebrał Palmowski (2017, s. 52). Podejmują one różnorodną tematykę, ze szczególnym uwzględnieniem studiów porównawczych w zakresie ochrony środowiska, badań kulturowych oraz współpracy gospodarczej.

Celem niniejszego artykułu jest odpowiedź na pytania: czy w UE wdrażającej tzw. miękkie zarządzanie na poziomie makroregionalnym można mówić o pogłębieniu integracji gospodarczej w ramach dodatkowego poziomu terytorialnego na przykładzie BSR; jakie kierunki wzajemnych powiązań handlowych są charakterystyczne dla BSR i jaki charakter przyjmują obserwowane zmiany (ilościowy, strukturalny, ilościowo-strukturalny) na przykładzie wymiany towarowej i usług; czy makroregion bałtycki stanowi konkurencyjny rynek zbytu w porównaniu do rynku unijnego (UE-28); jak na tle generalnych przemian w zakresie powiązań handlowych w BSR prezentują się polskie gospodarki lokalne.

W artykule zaprezentowano podstawowe aspekty wprowadzenia strategii makroregionalnych w UE, odwołano się do doświadczeń związanych z funkcjonowaniem pierwszej strategii makroregionalnej (Strategia UE dla regionu Morza Bałtyckiego; KE, 2009), jak również pokrótce omówiono proces integracji gospodarczej BSR. Druga część składa się z syntetycznego ujęcia problematyki delimitacji BSR (szeroko omawianego już w wielu pracach, ostatnio Palmowski, 2017; Cerić, 2019), przedstawienia przyjętego postępowa-

\footnotetext{
${ }^{1} \mathrm{~W}$ artykule termin „region Morza Bałtyckiego” (BSR) stosowany jest zamiennie z terminem „makroregion bałtycki".

2 VASAB - międzyrządowa sieć 11 krajów (czyli wszystkich krajów bałtyckich oraz Białorusi i Norwegii) reprezentowana przez ministrów odpowiedzialnych za rozwój i planowanie przestrzenne, promująca współpracę w zakresie planowania i rozwoju przestrzennego w BSR.
} 
nia badawczego i społeczno-gospodarczej charakterystyki regionu. Część trzecia zawiera omówienie najważniejszych prawidłowości w zakresie wymiany handlowej pomiędzy krajami BSR, z uwzględnieniem zmian ilościowych (wielkość wolumenu, dynamika zmian) i strukturalnych (specjalizacja wymiany towarowej i usług). W części czwartej podsumowano wyniki z uwzględnieniem kwestii potencjalnych kierunków pogłębiania integracji gospodarczej w regionie.

\section{Przegląd literatury}

\section{Makroregiony w UE jako element polityki integracyjnej}

Makroregion to obszar obejmujący terytorium kilku państw lub regionów, które łączą określone wspólne cechy bądź wyzwania. Strategie makroregionalne były jednym z elementów długofalowej wizji rozwoju UE zawartej w strategii rozwoju Europa 2020 - strategia na rzecz inteligentnego i zrównoważonego rozwoju sprzyjającego włączeniu społecznemu. Dokument nawiązuje do roli regionów, które stały się pełnoprawnymi uczestnikami procesów politycznych, na równi z państwami i instytucjami UE.

Strategie te są to zintegrowane programy dla określonych regionów geograficznych UE przyjęte przez Radę Europejską. Działania wdrażane w obrębie strategii mogą otrzymywać wsparcie z europejskich funduszy strukturalnych i inwestycyjnych. UE wprowadziła dotychczas cztery strategie makroregionalne obejmujące kilka obszarów polityki, 19 państw członkowskich i 8 krajów spoza UE: Strategia UE dla regionu Morza Bałtyckiego (2009), Strategia UE dla regionu Dunaju (2010), Strategia UE dla regionu adriatycko-jońskiego (2014) i Strategia UE dla regionu alpejskiego (2015).

Chociaż koncepcje strategii makroregionalnych są stosunkowo nową ideą, to stanowią po części odrodzenie się idei „superregionów europejskich” z lat 90. XX w. (Słomczyńska, 2014). W ostatnich latach rozwój strategii makroregionalnych zapoczątkował też ogromną dynamikę europejskiej współpracy terytorialnej (Gänzle i Kern, 2016). A pojawienie się nowego modelu podejmowania decyzji (wielostronnego, wielosektorowego i wielopoziomowego) stanowi próbę odejścia od dotychczasowych rozwiązań o charakterze hierarchicznym. Jak wskazuje Słomczyńska (2014, s. 6), „[u] podstaw koncepcji strategii makroregionalnych leży przekonanie, że poczucie tożsamości regionalnej mające wpływ na rozwój społeczny, gospodarczy i kulturowy, może być wykorzystane do zbudowania planu i strategii działania wykraczających poza istniejące rozwiązania (...)", a tym samym do pogłębiania relacji pomiędzy regionami i krajami. Zakłada się, że polityka spójności może też w sposób odgórny uzupełniać czynniki napędzające interakcje transgraniczne (Klatt i Winkler, 2020).

Strategie te mają na celu lepszą koordynację i interakcję między różnymi programami współpracy terytorialnej - regionalnymi, krajowymi i europejskimi - w tym samym makroregionie w celu wspólnego reagowania na wyzwania dotyczące rozwoju i planowania przestrzennego. Oczekuje się też, że nie stworzą one nowego programu lub nowego poziomu administracyjnego, ale raczej zdefiniują strategiczne wytyczne, co pozwoli lepiej zracjonalizować i zoperacjonalizować istniejące instrumenty (Perrin, 2020). 


\section{Region Morza Bałtyckiego}

Historia współpracy w regionie Morza Bałtyckiego sięga średniowiecza. North (2012) w swojej pracy w kontekście integracji regionu BSR nawiązuje aż do XIII-wiecznej Hanzy. Dlatego też skandynawski (bałtycki) model współpracy stanowił przykład pozytywnych doświadczeń współpracy regionalnej w Europie (Śmigerska-Belczak, 2017).

Chociaż nie ma jednej „właściwej” strategii makroregionalnej UE, to ta dla regionu Morza Bałtyckiego stała się strategią modelową dla pozostałych makroregionów. Opiera się ona na trzech głównych filarach tematycznych: ochrona morza (Save the Sea), wzrost integracji regionu (Connect the Region) i wzrost dobrobytu (Increase Prosperity) oraz podstawie horyzontalnej (KE, 2009). W obrębie każdego z filarów i w horyzontalnej podstawie wydzielono tzw. Obszary Tematyczne stanowiące podstawę realizacji projektów, które pozwalają na zwiększenia aktywności podmiotów zainteresowanych współpracą w regionie Morza Bałtyckiego. Ważne jest, że strategia nie dysponuje własnym funduszem. Jej beneficjenci ubiegają się o środki w ramach ogólnie dostępnych programów, głównie Programu współpracy transnarodowej Interreg Region Morza Bałtyckiego 2014-2020 (Leszczyna-Rzucidło, 2014).

Przyjęcie w 2009 r. Strategii UE dla regionu Morza Bałtyckiego zapoczątkowało nowe podejście UE do regionalizacji i rządzenia, którego istotą jest wielopoziomowa współpraca na poziomie krajowym, regionalnym i lokalnym z udziałem świata nauki, struktur regionalnych instytucji zarządzających programami operacyjnymi oraz sektora prywatnego (Palmowski, 2017). Jej powstanie zmusiło do przeformułowania działań wpasowujących się w nowe ramy przestrzenne, instytucjonalne i normatywne, w celu zapewnienia głębszej integracji gospodarczej i społecznej regionu i spójności z celami wyznaczonymi przez UE (Słomczyńska, 2014). A sama Strategia w swoich założeniach ma stwarzać możliwość dalszego zmniejszania barier w handlu i czerpania większych korzyści z jednolitego rynku w celu utrzymania zrównoważonego rozwoju (KE, 2009).

\section{Integracja gospodarcza na przykładzie gospodarki BSR}

W teoriach ekonomicznych integrację gospodarek narodowych można przypisać głównie handlowi zagranicznemu i bezpośrednim inwestycjom zagranicznym, które to stanowią powód do rozwoju współpracy między państwami i tworzenia stref wolnego handlu lub związków celnych (Zaucha et al., 2020).

Jednak wzorzec integracji BSR poprzez handel jest bardziej skomplikowany. BSR składa się z krajów o bardzo różnej bazie surowcowej, strukturze przemysłowej oraz poziomie rozwoju gospodarczego i społecznego. Wysoki udział całkowitych przepływów handlowych w BSR to wymiana z innymi krajami BSR, a dla części krajów największym partnerem handlowym jest inny kraj BSR (BT2050, 2019). Wysoki udział handlu wewnątrzgałęziowego również świadczy o rosnącej integracji gospodarczej krajów BSR, przy czym już wymiana handlowa Rosji wydaje się mieć charakter raczej międzygałęziowy, dlatego ma niewielki wpływ na integrację terytorialną w makroregionie (VASAB, 2010).

Jak wskazał Zaucha (2007), najsilniejsze wzajemne powiązanie poprzez handel jest widoczne w krajach skandynawskich, niemniej jednak w makroregionie funkcjonowały dwa centra integracji: jedno obejmujące trzy kraje skandynawskie UE i Niemcy, a drugie - trzy 
państwa bałtyckie, Polskę i Niemcy (do pewnego stopnia te powiązania wynikają z tranzytowego charakteru handlu na linii wschód-zachód).

Do pewnego stopnia takie zróżnicowanie stwarza możliwość wzajemnie korzystnej współpracy różnych gospodarek. Bliskość morza stanowi ważny czynnik wspierający handel, a jakość struktur instytucjonalnych wpływa na sposób kształtowania otoczenia biznesowego (Purju i Branten, 2013). Pozytywne efekty komplementarne mogą wynikać zarówno ze specjalizacji branżowej sąsiednich krajów w BSR, jak i z przepływów inwestycji bezpośrednich przy równoczesnym rozwoju technologicznym w obu grupach krajów (Tiits, 2006).

Z drugiej strony Tiits (2006) przestrzega, że integracja między krajami o zróżnicowanym poziomie gospodarczym może doprowadzić do przepływu produkcji przemysłowej od krajów bardziej rozwiniętych do mniej rozwiniętych oraz do odwrotnego przepływu siły roboczej. Takiej „płytkiej” integracji z europejskim systemem gospodarczym doświadczyły kraje bałtyckie w przeszłości (zamykanie nierentownych przedsiębiorstw, rozwój eksportu oparty głównie na towarach z branż zasobo- i pracochłonnych).

\section{Materiały, metody i obszar badania}

Jako obszar badań dla powiązań handlowych przyjęto region Morza Bałtyckiego (BSR) zdefiniowany zgodnie ze Strategią Unii Europejskiej dla regionu Morza Bałtyckiego (KE, 2009). Na potrzeby realizacji niniejszego badania z uwagi na dostępność danych na poziomie ogólnokrajowym jako BSR przyjęto całe terytorium 11 krajów: Białorusi, Danii, Finlandii, Estonii, Litwy, Łotwy, Niemiec, Norwegii, Polski, Rosji i Szwecji. Jest to obszar silnie zróżnicowany pod względem społecznym i gospodarczym (por. Fedorov i Mikhaylov, 2018; Kebza et al., 2019). Większość krajów (poza Rosją, Białorusią i Norwegią) należy do struktur UE, dzięki temu zagwarantowana jest swoboda przepływu osób, towarów i usług oraz kapitału, co dodatkowo może wpływać na relacje gospodarcze w obrębie krajów BSR.

Formalnie w Strategii region obejmuje części terytorium 2 krajów, tj. Niemiec i Rosji (por. Cerić, 2019), jednak w badaniach gospodarczych najczęściej uwzględnia się te kraje w całości (np. Paas i Tafenau, 2005; Purju i Branten, 2013). W przypadku Niemiec oficjalnie są to landy: Berlin, Brandenburgia, Brema, Hamburg, Meklemburgia Pomorze Przednie, Szlezwik-Holsztyn i Dolna Saksonia (tu tylko Lüneburg - NUTS 2), a do obszaru objętego programem w Rosji należą: Sankt Petersburg i otaczający go obwód leningradzki, Republika Karelii oraz obwody: kaliningradzki, murmański, nowogrodzki i pskowski (KE, 2009; VASAB, 2010; BT2050, 2019).

Liczba ludności w państwach objętych badaniem w 2019 r. wyniosła 310,1 m/n (106,1 mln przy uwzględnieniu zawężenia terytorium do regionów w Niemczech i Rosji), blisko $18 \%$ ludności Niemiec mieszkała na obszarze BSR, zaledwie 7,4\% - w przypadku Rosji (tab. 1). Ludność krajów regionu należących do UE stanowiła w tym czasie 26,9\% ludności całej Wspólnoty (prawie 1/5 przy uwzględnieniu zawężenia terytorium do regionów w Niemczech i Rosji).

BSR jest nadal biedniejszy niż średnia UE, ale dystans pomiędzy nimi maleje, ponieważ PKB BSR rośnie szybciej niż średnia UE (BT2050, 2019). Pod względem PKB per capita w parytecie siły nabywczej (WB, 2019) wartość 50 tys. dolarów przekroczyły Norwegia, Dania, Niemcy, Szwecja i Finlandia, tym samym znalazły się one w grupie 25 państw o naj- 
Tabela 1. Charakterystyka krajów BSR

Characteristics of the BSR countries

\begin{tabular}{|l|c|c|c|}
\hline \multirow{2}{*}{ Kraj } & $\begin{array}{c}\text { Ludność w 2019 r. } \\
\text { (w tym w obszarze BSR) }\end{array}$ & PKB per capita w 2019 r. & $\begin{array}{c}\text { Udział usług w strukturze } \\
\text { zatrudnienia w 2019 r. }\end{array}$ \\
\cline { 2 - 4 } Białoruś & mln & PPP $\$$ \\
Dania & 9,4 & 19943 & 58,53 \\
Estonia & 5,8 & 59830 & 79,35 \\
Finlandia & 1,3 & 38811 & 67,28 \\
Litwa & 5,5 & 51324 & 74,21 \\
Łotwa & 2,7 & 38214 & 67,21 \\
Niemcy & 1,9 & 32205 & 69,52 \\
Norwegia & $83,0(14,9)$ & 56052 & 71,75 \\
Polska & 5,3 & 66832 & 78,67 \\
Rosja & 37,9 & 34218 & 58,83 \\
Szwecja & $146,7(10,9)$ & 29181 & 67,57 \\
\hline
\end{tabular}

Opracowanie własne na podstawie Eurostat (2020) i WB (2020).

wyższym PKB. Spośród państw regionu najniższą wartość (poniżej 20 tys.) odnotowano dla Białorusi. Również struktura zatrudnienia w państwach regionu była zróżnicowana. Kraje skandynawskie i Niemcy charakteryzowały się niskim udziałem rolnictwa (poniżej 4\%) oraz wysokim udziałem usług (powyżej 70\%) w strukturze zatrudnienia ludności. W pozostałych krajach udział zatrudnionych w rolnictwie był zdecydowanie wyższy np. Białoruś $-11,02 \%$ oraz Polska - 9,23\%, a zatrudnienie w usługach wyniosło poniżej 70\%, dla Polski i Białorusi nawet poniżej 60\% (WB, 2020). W BSR rozwój gospodarczy krajów o stabilnej gospodarce rynkowej znacznie różni się od rozwoju krajów, które przeszły transformację polityczno-gospodarczą w latach 90. XX w. Różnice te odzwierciedla nie tylko duża rozpiętość PKB na mieszkańca i struktura zatrudnienia, ale widoczne są one też w obszarze współpracy gospodarczej (struktura kierunkowa i specjalizacje eksportu, rozkład przestrzenny FDI, stopień kooperacji regionalnej pomiędzy przedsiębiorstwami).

W 2019 r. największym eksporterem spośród państw BSR były Niemcy (3 miejsce na świecie), potem kolejno Rosja - 16, Polska - 26, Szwecja - 30, Dania - 35, Norwegia - 36, Finlandia 48, Litwa - 66, Białoruś - 68, Estonia - 80, Łotwa - 82 (WF, 2020). Do głównych partnerów wymiany handlowej towarowej państw BSR można zaliczyć kraje makroregionu oraz państwa UE spoza BSR, tj. Holandię i Francję (tab. 2). Z państw pozaeuropejskich bardzo ważnym importerem były Chiny, a Stany Zjednoczone - partnerem eksportowym dla Finlandii, Niemiec i Szwecji. W strukturze towarowej zarówno eksportu, jak i importu, dominowały maszyny i urządzenia mechaniczne oraz paliwa i oleje mineralne oraz produkty ich destylacji. Produkty farmaceutyczne były główną kategorią eksportu towarów w Danii, maszyny i urządzenia elektryczne oraz ich części - w Estonii, a drewno i artykuły z drewna - na Łotwie. Najważniejszymi partnerami wymiany usługowej państw BSR spoza regionu były Stany Zjednoczone, Wielka Brytania, Francja i Szwajcaria. W eksporcie usług w krajach objętych badaniem (Eurostat, 2018) dominują usługi transportowe (Dania, Estonia, Litwa, Łotwa, Polska). Pozostałe usługi gospodarcze, tj. usługi badawczo- 
-rozwojowe, usługi prawne, księgowe, doradztwa w zakresie zarządzania i inne stanowiły najważniejszą grupę usług w Niemczech i Szwecji, a usługi telekomunikacyjne, informatyczne i informacyjne - w Finlandii. W imporcie usługi transportowe stanowiły największy udział w Danii, Estonii, Litwie i Łotwie, a pozostałe usługi gospodarcze - w Finlandii, Niemczech, Polsce i Szwecji. Struktura towarowa lub usługowa handlu w poszczególnych krajach nie jest jednorodna, jest natomiast silnie skorelowana ze specjalizacją poszczególnych gospodarek.

W artykule wykorzystano materiały z różnych źródeł. Porównania międzynarodowe oparto przede wszystkim na danych gospodarczych o produkcie krajowym brutto, handlu zagranicznym towarami i międzynarodowej wymianie usług pochodzących z baz danych Banku Światowego (WB, 2020), Eurostatu (Eurostat, 2020) oraz krajowych baz danych (Norwegii - Statistik sentralbyrå, 2020). Z kolei jako podstawę badań studium przypadku dotyczącego towarowych powiązań handlowych w ujęciu regionalnym na obszarze Polski wykorzystano dane pochodzące z Krajowej Administracji Skarbowej obejmujące system sprawozdawczości obrotów towarowych z krajami UE (INTRASTAT) i spoza UE (EXTRASTAT).

Analiza koncentruje się na ocenie przemian powiązań handlowych towarowych i wymiany usług w regionie Morza Bałtyckiego w latach 2011-2019 (w przypadku wymiany usług - 2011-2018 z uwagi na dostępność danych). Okres ten umożliwia zbadanie najważniejszych tendencji w warunkach stabilizacji uwarunkowań zewnętrznych, tj. już po ustanowieniu Strategii UE dla regionu Morza Bałtyckiego oraz po okresie recesji wynikającej z kryzysu światowego z 2008 r. Na potrzeby oceny struktur przedmiotowych obrotu, w badaniu wykorzystano standardową klasyfikację handlu międzynarodowego (Standard International Trade Classification, w skrócie SITC), wykorzystywaną do statystyki handlu zagranicznego towarów, dzielącą całkowity wolumen eksportu bądź importu na sekcje (1-2 - żywność, napoje i wyroby tytoniowe, 3 - surowce, 4 - produkty energetyczne, 5-chemikalia, 6-7-maszyny, urządzenia i sprzęt transportowy, 8-9-inne wyroby fabryczne). Natomiast w analizie wymiany usług wykorzystano dane o wartości usług zgodnie z Rozszerzoną Klasyfikacją Usług w Bilansie Płatniczym (EBOPS), w ramach której badane są następujące główne grupy usług: produkcyjne w odniesieniu do nakładów rzeczowych będących własnością osób trzecich (usługi uszlachetniania), transportowe, pocztowe i kurierskie, podróże, budowlane, ubezpieczeniowe i emerytalne, finansowe, opłaty z tytułu użytkowania własności intelektualnej, telekomunikacyjne, informatyczne i informacyjne, pozostałe usługi gospodarcze, usługi kulturalne, rekreacyjne i świadczone dla ludności, usługi rządowe oraz pozostałe usługi niesklasyfikowane.

Analiza na podstawie zebranego materiału statystycznego wykorzystuje metodę wskaźnikową oraz metodę kartograficznej analizy danych. W artykule przede wszystkim wykorzystano wskaźniki natężenia i dynamiki zjawisk w celu wyodrębnienia najważniejszych tendencji w zakresie powiązań handlowych w obrębie BSR, w tym wzajemnych relacji pomiędzy krajami oraz zróżnicowania struktur handlowych, z uwzględnieniem porównań względem analogicznych trendów w UE. Jednocześnie podjęto próbę pogłębienia wiedzy na temat relacji polskich regionów (powiatów) z krajami BSR, w szczególności z obszarami, z którymi relacje handlowe były dotychczas słabsze, tj. z krajami skandynawskimi, stanowiącymi do pewnego stopnia wyznacznik współpracy gospodarczej w obrębie BSR.

Ponadto, rozpatrując poziom dywersyfikacji handlu zagranicznego, posłużono się wskaźnikiem koncentracji Herfindahla-Hirschmanna; do obliczenia wskaźnika wykorzystano wzór: 
gdzie:

$$
H H_{t}=\frac{\sqrt{\sum_{i=1}^{n}\left(\frac{x_{i t}}{X_{t}}\right)^{2}}-\sqrt{\frac{1}{n}}}{1-\sqrt{\frac{1}{n}}}
$$

$x_{i t}$ - wartość eksportu towarów gałęzi $i$ w roku $t$

$X_{t}$ - wartość całkowita eksportu kraju w roku $t$

$n$ - liczba gałęzi.

Tabela 2. Podstawowe struktury kierunkowo-towarowe handlu zagranicznego krajów BSR Basic geographic and product structures of the BSR countries' foreign trade

\begin{tabular}{|c|c|c|c|c|c|}
\hline \multirow{3}{*}{ Lp. } & \multirow{3}{*}{ Kraj } & \multicolumn{4}{|c|}{ Międzynarodowa wymiana towarowa w 2019 r. } \\
\hline & & \multicolumn{2}{|c|}{ Główni partnerzy } & \multicolumn{2}{|c|}{ Główny przedmiot obrotu } \\
\hline & & w eksporcie & w imporcie & w eksporcie & w imporcie \\
\hline 1. & Białoruś & $\begin{array}{l}\text { Rosja, Ukraina, } \\
\text { Wielka Brytania }\end{array}$ & $\begin{array}{l}\text { Rosja, Chiny, } \\
\text { Niemcy }\end{array}$ & $\begin{array}{l}\text { paliwa i oleje mine- } \\
\text { ralne oraz produkty } \\
\text { ich destylacji }\end{array}$ & $\begin{array}{l}\text { paliwa i oleje mineralne } \\
\text { oraz produkty ich } \\
\text { destylacji }\end{array}$ \\
\hline 2. & Dania & $\begin{array}{l}\text { Niemcy, Szwecja, } \\
\text { Norwegia }\end{array}$ & $\begin{array}{l}\text { Niemcy, Szwecja, } \\
\text { Holandia }\end{array}$ & $\begin{array}{l}\text { produkty } \\
\text { farmaceutyczne }\end{array}$ & $\begin{array}{l}\text { maszyny i urządzenia me- } \\
\text { chaniczne oraz ich części }\end{array}$ \\
\hline 3. & Estonia & $\begin{array}{l}\text { Finlandia, Szwecja, } \\
\text { Łotwa }\end{array}$ & $\begin{array}{l}\text { Niemcy, Rosja, } \\
\text { Finlandia }\end{array}$ & $\begin{array}{l}\text { maszyny i urządze- } \\
\text { nia elektryczne oraz } \\
\text { ich części }\end{array}$ & $\begin{array}{l}\text { paliwa i oleje mineralne } \\
\text { oraz produkty ich } \\
\text { destylacji }\end{array}$ \\
\hline 4. & Finlandia & $\begin{array}{l}\text { Niemcy, Szwecja, } \\
\text { Stany Zjednoczone }\end{array}$ & $\begin{array}{l}\text { Niemcy, Rosja, } \\
\text { Szwecja }\end{array}$ & $\begin{array}{l}\text { maszyny i urządze- } \\
\text { nia mechaniczne } \\
\text { oraz ich części }\end{array}$ & $\begin{array}{l}\text { paliwa i oleje mineralne } \\
\text { oraz produkty ich } \\
\text { destylacji }\end{array}$ \\
\hline 5. & Litwa & $\begin{array}{l}\text { Rosja, Łotwa, } \\
\text { Polska }\end{array}$ & $\begin{array}{l}\text { Rosja, Polska, } \\
\text { Niemcy }\end{array}$ & $\begin{array}{l}\text { paliwa i oleje mine- } \\
\text { ralne oraz produkty } \\
\text { ich destylacji }\end{array}$ & $\begin{array}{l}\text { paliwa i oleje mineralne } \\
\text { oraz produkty ich } \\
\text { destylacji }\end{array}$ \\
\hline 6. & Łotwa & $\begin{array}{l}\text { Litwa, Estonia, } \\
\text { Rosja }\end{array}$ & $\begin{array}{l}\text { Litwa, Niemcy, } \\
\text { Polska }\end{array}$ & $\begin{array}{l}\text { drewno i artykuły } \\
\text { z drewna }\end{array}$ & $\begin{array}{l}\text { maszyny i urządzenia } \\
\text { elektryczne oraz ich części }\end{array}$ \\
\hline 7. & Niemcy & $\begin{array}{l}\text { Stany Zjednoczo- } \\
\text { ne, Francja, Chiny }\end{array}$ & $\begin{array}{l}\text { Chiny, Holandia, } \\
\text { Stany Zjednoczone }\end{array}$ & $\begin{array}{l}\text { maszyny i urządze- } \\
\text { nia mechaniczne } \\
\text { oraz ich części }\end{array}$ & $\begin{array}{l}\text { maszyny i urządzenia me- } \\
\text { chaniczne oraz ich części }\end{array}$ \\
\hline 8. & Norwegia & $\begin{array}{l}\text { Wielka Brytania, } \\
\text { Niemcy, Holandia }\end{array}$ & $\begin{array}{l}\text { Szwecja, Niemcy, } \\
\text { Chiny }\end{array}$ & $\begin{array}{l}\text { paliwa i oleje mine- } \\
\text { ralne oraz produkty } \\
\text { ich destylacji }\end{array}$ & $\begin{array}{l}\text { maszyny i urządzenia me- } \\
\text { chaniczne oraz ich części }\end{array}$ \\
\hline 9. & Polska & $\begin{array}{l}\text { Niemcy, Czechy, } \\
\text { Wielka Brytania }\end{array}$ & $\begin{array}{l}\text { Niemcy, Chiny, } \\
\text { Rosja }\end{array}$ & $\begin{array}{l}\text { maszyny i urządze- } \\
\text { nia mechaniczne } \\
\text { oraz ich części }\end{array}$ & $\begin{array}{l}\text { maszyny i urządzenia me- } \\
\text { chaniczne oraz ich części }\end{array}$ \\
\hline 10. & Rosja & $\begin{array}{l}\text { Chiny, Holandia, } \\
\text { Niemcy }\end{array}$ & $\begin{array}{l}\text { Chiny, Niemcy, } \\
\text { Białoruś }\end{array}$ & $\begin{array}{l}\text { paliwa i oleje mine- } \\
\text { ralne oraz produkty } \\
\text { ich destylacji }\end{array}$ & $\begin{array}{l}\text { maszyny i urządzenia me- } \\
\text { chaniczne oraz ich części }\end{array}$ \\
\hline 11. & Szwecja & $\begin{array}{l}\text { Norwegia, Niemcy, } \\
\text { Stany Zjednoczone }\end{array}$ & $\begin{array}{l}\text { Niemcy, Holandia, } \\
\text { Norwegia }\end{array}$ & $\begin{array}{l}\text { maszyny i urządze- } \\
\text { nia mechaniczne } \\
\text { oraz ich części }\end{array}$ & $\begin{array}{l}\text { maszyny i urządzenia me- } \\
\text { chaniczne oraz ich części }\end{array}$ \\
\hline
\end{tabular}

- brak danych

Opracowanie własne na podstawie Eurostat (2020), WB (2020), Statistik sentralbyrå (2020) i TE (2020). 
Wskaźnik ten określa, w jakim stopniu eksport jest skoncentrowany na niewielkiej liczbie produktów lub usług (Misztal, 2011; Boehe i Jiménez, 2016). Wskaźnik ma charakter znormalizowany, co oznacza, że wartość równa 1 świadczy o całkowitej koncentracji eksportu; natomiast wartości zbliżające się do 0 identyfikują wysoką dywersyfikację eksportu.

\begin{tabular}{|c|c|c|c|c|}
\hline \multirow{3}{*}{ Lp. } & \multicolumn{4}{|c|}{ Międzynarodowy handel usługami w 2018 r. } \\
\hline & \multicolumn{2}{|c|}{ Główni partnerzy } & \multicolumn{2}{|c|}{ Główny przedmiot obrotu } \\
\hline & w eksporcie & w imporcie & w eksporcie & w imporcie \\
\hline 1. & - & - & - & - \\
\hline 2. & $\begin{array}{l}\text { Wielka Brytania, Niemcy, } \\
\text { Stany Zjednoczone }\end{array}$ & $\begin{array}{l}\text { Wielka Brytania, Niemcy, } \\
\text { Stany Zjednoczone }\end{array}$ & usługi transportowe & $\begin{array}{l}\text { usługi } \\
\text { transportowe }\end{array}$ \\
\hline 3. & Finlandia, Szwecja, Niemcy & Finlandia, Szwecja, Łotwa & usługi transportowe & $\begin{array}{l}\text { usługi } \\
\text { transportowe }\end{array}$ \\
\hline 4. & $\begin{array}{l}\text { Szwecja, Stany Zjednoczo- } \\
\text { ne, Niemcy }\end{array}$ & $\begin{array}{l}\text { Szwecja, Niemcy, Wielka } \\
\text { Brytania }\end{array}$ & $\begin{array}{l}\text { usługi telekomunika- } \\
\text { cyjne, informatyczne } \\
\text { i informacyjne }\end{array}$ & $\begin{array}{l}\text { pozostałe usługi } \\
\text { gospodarcze }\end{array}$ \\
\hline 5. & Niemcy, Rosja, Francja & Białoruś, Polska, Rosja & usługi transportowe & $\begin{array}{l}\text { usługi } \\
\text { transportowe }\end{array}$ \\
\hline 6. & $\begin{array}{l}\text { Szwecja, Rosja, Wielka } \\
\text { Brytania }\end{array}$ & Litwa, Estonia, Rosja & usługi transportowe & $\begin{array}{l}\text { usługi } \\
\text { transportowe }\end{array}$ \\
\hline 7. & $\begin{array}{l}\text { Stany Zjednoczone, Wielka } \\
\text { Brytania, Szwajcaria }\end{array}$ & $\begin{array}{l}\text { Stany Zjednoczone, Wielka } \\
\text { Brytania, Francja }\end{array}$ & $\begin{array}{l}\text { pozostałe usługi } \\
\text { gospodarcze }\end{array}$ & $\begin{array}{l}\text { pozostałe usługi } \\
\text { gospodarcze }\end{array}$ \\
\hline 8. & - & - & - & - \\
\hline 9. & $\begin{array}{l}\text { Niemcy, Szwajcaria, Wielka } \\
\text { Brytania }\end{array}$ & $\begin{array}{l}\text { Niemcy, Wielka Brytania, } \\
\text { Francja }\end{array}$ & usługi transportowe & $\begin{array}{l}\text { pozostałe usługi } \\
\text { gospodarcze }\end{array}$ \\
\hline 10. & - & - & - & - \\
\hline 11. & $\begin{array}{l}\text { Norwegia, Wielka Brytania, } \\
\text { Stany Zjednoczone }\end{array}$ & $\begin{array}{l}\text { Stany Zjednoczone, Wielka } \\
\text { Brytania, Niemcy }\end{array}$ & $\begin{array}{l}\text { pozostałe usługi } \\
\text { gospodarcze }\end{array}$ & $\begin{array}{l}\text { pozostałe usługi } \\
\text { gospodarcze }\end{array}$ \\
\hline
\end{tabular}




\section{Wyniki}

W latach 2011-2019 przeciętny udział eksportu towarów i usług krajów BSR nieznacznie wzrósł do poziomu 46,2\% PKB (wobec 44,3\% w 2011 r.). W największym stopniu wzrost ten dotyczył Polski (+13,2 p.p.) i Litwy (+5,0 p.p.). Trzy kraje odnotowały w tym okresie spadek znaczenia wymiany handlowej. Były to: Estonia (-13,3 p.p.), Białoruś (-12,0 p.p.) oraz Norwegia (-4,3 p.p.). W pozostałych krajach BSR udział handlu charakteryzował się stabilnym, choć zdecydowanie zróżnicowanym poziomem. Kraje bałtyckie (Litwa, Łotwa i Estonia) osiągnęły najwyższy poziom otwartości na gospodarkę światową (w 2019 r. odpowiednio 78,1; 57,8 i 72,6\%). Na drugim biegunie znajduje się gospodarka rosyjska w dużym stopniu oparta na handlu surowcami z 28,3\% udziałem eksportu w PKB. Warto podkreślić, że kraje BSR z tzw. starej Unii nie wykazują obecnie większych zmian koniunkturalnych analizowanego wskaźnika.

\section{Handel zagraniczny towarami w BSR}

Cechą charakterystyczną najbardziej zaawansowanych ugrupowań integracyjnych jest fakt, że dużą część prowadzonej przez nich wymiany handlowej stanowią obroty pomiędzy krajami należącymi do ugrupowania. Analogicznie można odnieść się do skali handlu wewnątrz makroregionu jako miary siły powiązań w BSR. Dla krajów BSR udział wymiany towarowej z krajami UE-28 stanowił w 2019 r. 60,0\%. Z kolei handel wewnątrz makroregionu to aż $23,7 \%$ wymiany całkowitej. Oba udziały w badanym okresie kształtowały się na zbliżonym poziomie.

Niewątpliwie wszelkie przemiany w zakresie handlu towarami mają charakter trwały, w dużym stopniu wynikają też z historycznych powiązań. Stąd też wyraźnie zarysowują się tradycyjne kierunki powiązań w makroregionie (np. Polska-Niemcy, Białoruś-Rosja, wzajemne relacje w krajach skandynawskich). Makroregion nadal różnicuje się pod względem siły i kierunków powiązań (ryc. 1), choć obraz ten jest zdecydowanie bardziej skomplikowany niż podziały na kraje UE i spoza UE, czy też tzw. nowej i starej UE (np. silne powiązania Niemcy-Rosja).

Łącznie wielkość obrotów wzajemnych pomiędzy krajami BSR w handlu towarowym wyniosła w 2019 r. 1 057,0 mld euro, natomiast krajów BSR z krajami UE-28 aż 2676,5 mld euro. W latach 2011-2019 dynamika w obrotach towarowych dla makroregionu bałtyckiego była nieco niższa niż z krajami UE-28 (o 1,7 p.p.) i wyniosła 120,9. Dla analiz stopnia intensyfikacji stosunków gospodarczych warto wskazać, że umiarkowanie wyższym tempem wzrostu odznaczał się eksport do krajów BSR niż na rynki UE-28 $(127,3$ wobec 119,7$)$. O ile kraje BSR we wzajemnych relacjach odnotowały w omawianym okresie przyrosty obrotów handlowych, o tyle ta tendencja nie była charakterystyczna dla obrotów ogółem (spadki wolumenu obrotów objęły Norwegię, Białoruś i Rosję, tym samym udział BSR w ich obrotach nieznacznie wzrósł).

Spośród krajów BSR największe obroty w handlu towarami wewnątrz makroregionu są charakterystyczne dla Niemiec (297,3 mld euro), Polski (187,3 mld euro), Rosji (129,3 mld euro) i Szwecji (125,9 mld euro). Marginalne znaczenie ma wymiana handlowa dwóch najmniejszych krajów: Łotwy (20,2 mld euro) i Estonii (20,6 mld euro).

W latach 2011-2019 ekspansja na rynki krajów BSR była relatywnie bardziej atrakcyjna dla nowych krajów UE (tj. Polski, Litwy i Łotwy). W ich przypadku tempo wzrostu obrotów 
było najwyższe (odpowiednio 46,6; 26,9 i 22,3\%; por. Powiązania towarowe w BSR w ujęciu lokalnym na przykładzie Polski - w dalszej części artykułu).

Mimo największego wolumenu obrotów spośród krajów BSR dla gospodarki niemieckiej makroregion nie stanowi tak istotnego rynku zbytu produktów na tle UE-28 (BSR to zaledwie $12,2 \%$ obrotów ogółem). Na drugim biegunie znajdują sią kraje bałtyckie z udziałem od 59,8\% na Litwie do 67,5\% w Estonii. Dla krajów bałtyckich rynki BSR stanowią też główne rynki wymiany towarowej z UE-28 (najsilniejsza integracja gospodarcza w makroregionie). Rynek krajów BSR jest umiarkowanie istotny dla krajów skandynawskich i Polski (średni udział 41,7\%).

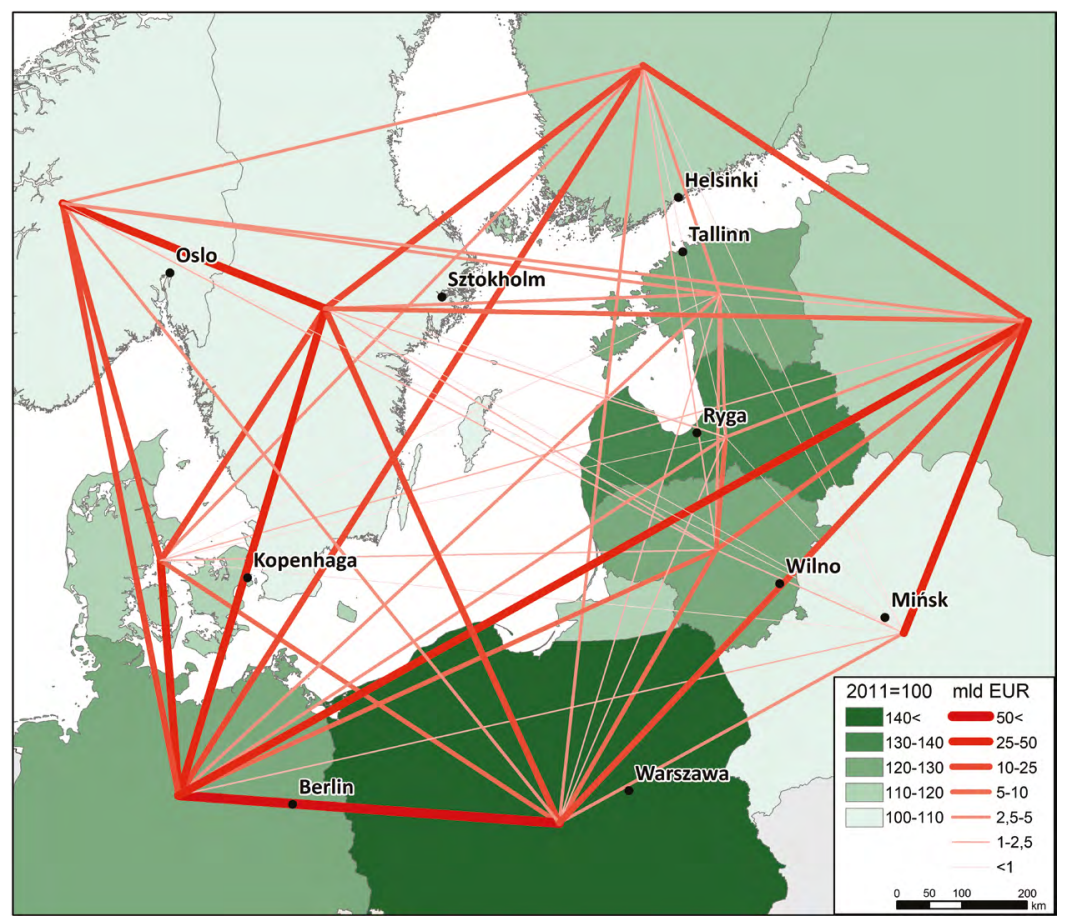

Ryc. 1. Obroty handlu zagranicznego towarami pomiędzy krajami BSR w 2019 r. i ich dynamika 2011-2019 Turnover of foreign trade in goods between the BSR countries in 2019 and its dynamics in the years 2011-2019 Opracowanie własne na podstawie danych Eurostatu (2020).

\section{Międzynarodowa wymiana usług w BSR}

Jeszcze do niedawna międzynarodowy handel usługami miał znaczenie marginalne, dopiero od II połowy XX w. (w epoce serwicyzacji) wzrosło zainteresowanie prawidłowościami obrotu usługami, uwzględniające różnice względem wymiany towarowej (m.in. brak konieczności przemieszczenia podmiotu realizującego usługi) oraz czynniki odgrywające wpływ na jego rozwój (takie jak postęp techniki i możliwości świadczenia usług na odległość).

Również w krajach BSR międzynarodowy handel usługami zyskuje coraz bardziej na znaczeniu. W latach 2011-2018 obserwuje się stabilny wzrost obrotów usługami (o bli- 
sko połowę, 46,3\%) oraz podobną tendencję jeśli chodzi o tempo wzrostu obrotów krajów BSR z krajami UE $(56,8 \%)$. Wolniejszy wzrost obrotów usługowych pomiędzy krajami BSR w porównaniu do tempa wzrostu wymiany handlowej z krajami UE w okresie ostatnich 8 lat przełożył się na spadek ich udziału w łącznych obrotach z 20,6\% na 19,8\% obrotów ogółem. Tempo wzrostu przychodów z eksportu usług zdecydowanie przewyższa wzrost wpływów z eksportu towarów, a ich sprzedaż na rynek krajów BSR wyróżnia się silniejszym zróżnicowaniem wewnętrznym.

W BSR wymiana usług odgrywa coraz bardziej ważną rolę, jednak podobnie jak w przypadku wymiany towarowej znacząca jej większość dostarczana jest na rynki państw unijnych nienależących do BSR. Można przypuszczać, że do pewnego stopnia intensyfikacja eksportu usług związana jest z wcześniejszym napływem kapitału. W 2018 r. wzajemne obroty pomiędzy krajami BSR wyniosły 195,8 mld euro, podczas gdy obroty ze wszystkimi krajami UE - już ponad 560 mld euro.

Niekwestionowanym liderem w zakresie obrotu usługami są Niemcy i Szwecja, u których zaobserwowano obroty na poziomie odpowiednio 45,1 i 43,1 mld euro. W grupie państw BSR wysokie obroty osiągnęły również Dania i Polska (odpowiednio 36,4 i 31,2 mld euro). Z ryc. 2 jednoznacznie wynika, że w przypadku obrotu usługami makroregion bałtycki charakteryzuje swoisty dualizm. Poza wymienionymi krajami wymiana usług na pozostałym obszarze ma zdecydowanie mniejszy wolumen. Relacje gospodarcze w tym zakresie mają minimalne znaczenie (są w fazie inicjalnej rozwoju współpracy).

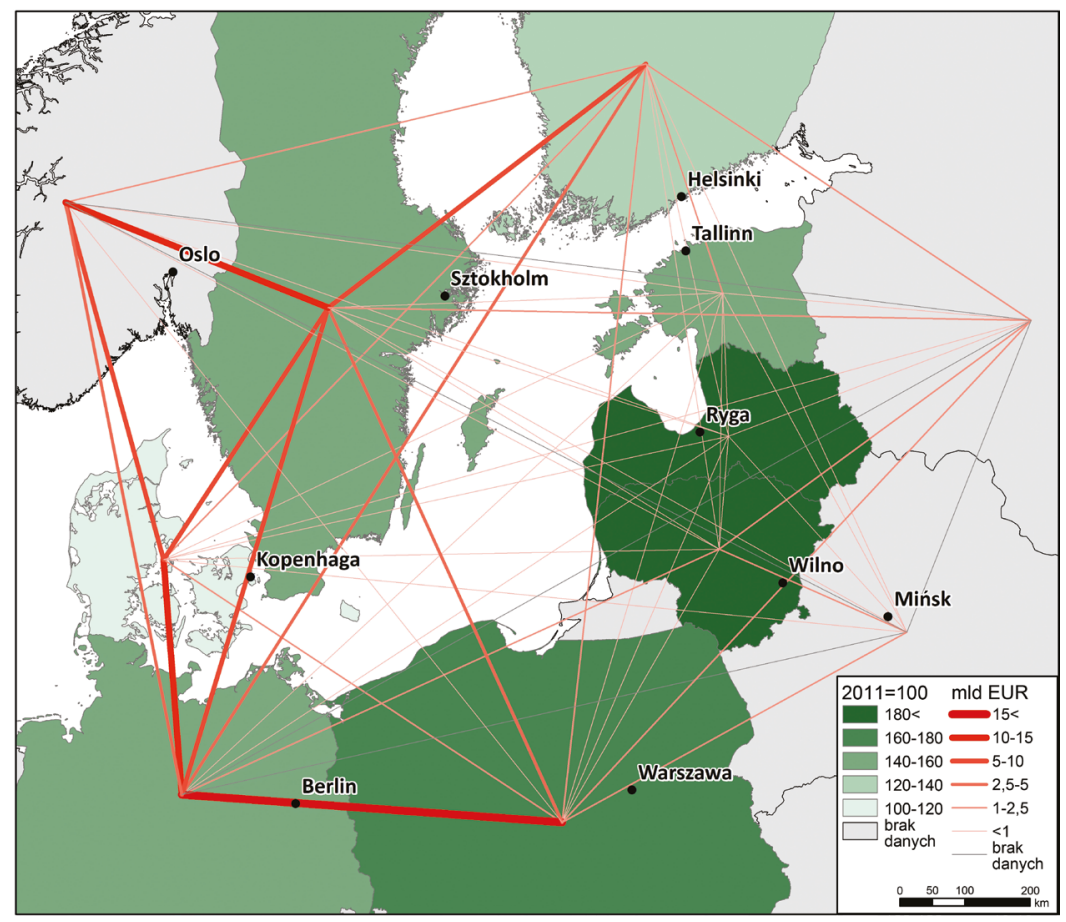

Ryc. 2. Międzynarodowa wymiana usług pomiędzy krajami BSR w 2018 r. i jej dynamika 2011-2018 International trade in services between the BSR countries in 2018 and its dynamics in the years 2011-2018 Opracowanie własne na podstawie danych Eurostatu (2020). 
W latach 2011-2018 największy wzrost roli usług nastąpił w wymianie międzynarodowej pomiędzy Litwą i Łotwą a krajami BSR. W tym przypadku należy zwrócić uwagę nie tylko na wysoką dynamikę wzrostu wartości, ale też i wysoki udział obrotów z krajami BSR w obrotach usługami ogółem (w przypadku Litwy aż 64,2\%).

We wszystkich krajach BSR tempo przyrostu obrotów wzajemnych wewnątrz regionu było nieco niższe niż z krajami UE-28. Wyjątek stanowi Szwecja z dynamiką na poziomie 144,1\%, wobec 139,5\% z krajami UE-28. Z kolei kraje bałtyckie i Dania zwiększyły swoje obroty z krajami UE-28 w zdecydowanie większym stopniu niż z krajami BSR (Litwa prawie trzykrotny wzrost, a dwukrotny w obrębie BSR). W latach 2011-2018 również udział wpływów z eksportu usług do krajów BSR we wpływach ogółem systematycznie malał, jedynie na Litwie i Łotwie eksport wewnątrz makroregionu zyskał na znaczeniu (odpowiednio z 51,7 do $64,2 \%$ oraz z 43,7 do 50,8\%). Odmienna sytuacja miała miejsce jeśli chodzi o wymianę usług z krajami UE 28, w większości krajów BSR udział ten wzrósł.

\section{Struktura powiązań handlowych w BSR}

Znaczenie makroregionu bałtyckiego w relacjach gospodarczych poszczególnych krajów jest silnie zróżnicowane, zdecydowanie większe jest dla małych gospodarek krajów bałtyckich (specjalizacja kierunkowa) niż największej gospodarki unijnej Niemiec, dla której BSR nie może konkurować z większymi rynkami zbytu w Europie czy na świecie, np. Francją i USA (ryc. 3). Generalnie koncentracja eksportu (kierunkowa i strukturalna) jest powiązana ze zmianami popytu wewnętrznego, polityką państwa, czy też wielkością i strukturą bezpośrednich inwestycji zagranicznych, a dywersyfikacja może przyczyniać się do wzrostu gospodarczego i większej stabilności wpływów (por. Misztal, 2011).

W BSR największe zmiany w obrębie wskaźnika koncentracji odnotowywane są dla obrotu usługami, co potwierdza tezę o większej specjalizacji gospodarek w zakresie świadczenia usług za granicą. W Szwecji i na Litwie poziom koncentracji w latach 2011-2018 wzrósł, a w pozostałych krajach był niższy, w tym najniższy w Finlandii $(0,1676)$. Z kolei struktury towarowe eksportu odznaczają się niższym poziomem koncentracji. Wynika to m.in. z faktu, że eksport usług jest operacją wymagającą więcej zaangażowania niż handel towarami (doświadczenie wielu lat prowadzenia wzajemnych transakcji) i jednocześnie produkcja towarowa jest bardziej zdywersyfikowana w gospodarkach narodowych (silnie rozwinięty handel wewnątrzgałęziowy). Poziom koncentracji towarowej był najwyższy w Niemczech i Finlandii. Największą dywersyfikacją produktową charakteryzował się natomiast eksport łotewski do krajów BSR.

W strukturze eksportu krajów BSR dominującą rolę odgrywa wymiana wewnątrzgałęziowa obejmująca towary o relatywnie wyższym stopniu przetworzenia. W 2019 r. maszyny, urządzenia i pojazdy (oraz ich części) stanowiły ponad 1/3 eksportu towarów krajów BSR wewnątrz makroregionu (38,6\%) i udział ten nieznacznie wzrósł od 2011 r. Kolejno, różne wyroby przetworzone w obrocie to blisko $1 / 3$ wymiany. Niemniej jednak na poziomie poszczególnych krajów ogólna struktura handlu była już bardziej zdywersyfikowana. Na przykład Dania, Litwa i Łotwa miały relatywnie wyższy udział eksportu produktów rolno-spożywczych (ponad 10\%). Z kolei również Dania, Litwa i Finlandia w strukturze eksportu wykazywały ponad $10 \%$ udział paliw i ich pochodnych. W okresie po rozszerzeniu UE w 2004 r. nie zaszły też większe zmiany w konkurencyjności eksportu towarów regionu BSR. W tzw. nowych krajach UE w tym okresie zauważalny był wzrost udziału dóbr zaawansowanych technologicznie (najpierw przemysł samochodowy, potem też sprzęt 


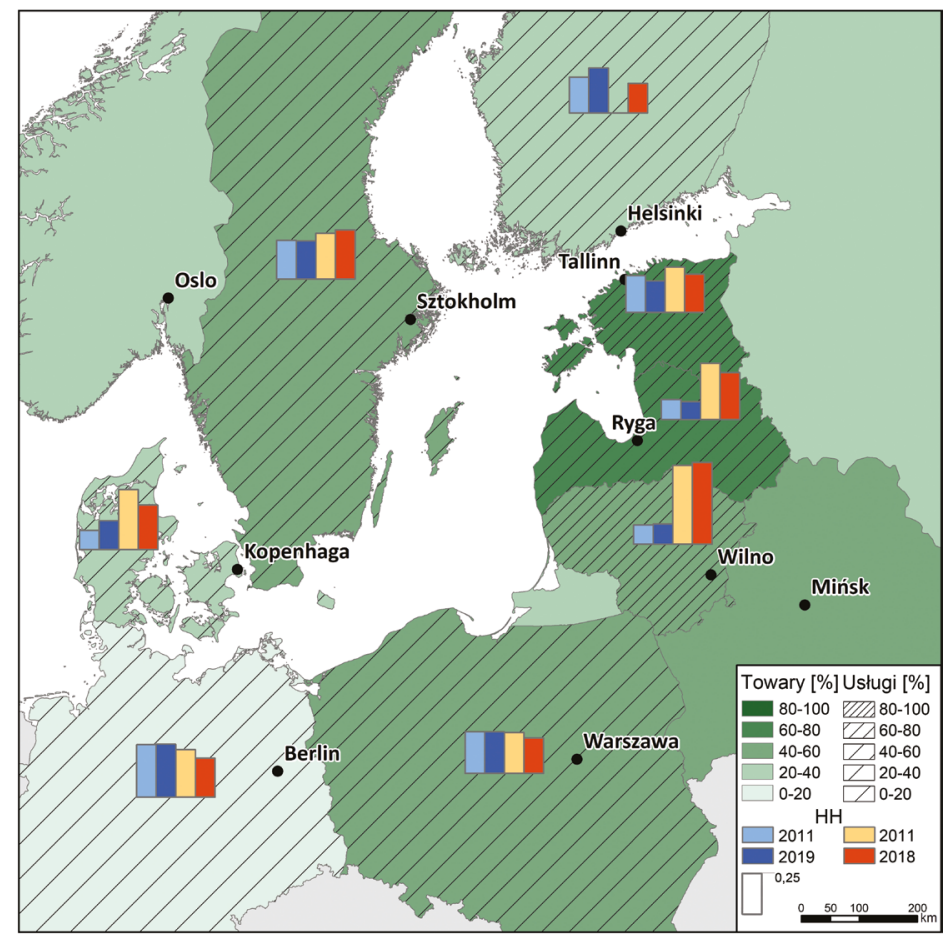

Ryc. 3. Udział eksportu towarów i usług do krajów BSR w wymianie ogółem w 2019 r. (2018 - dla usług) oraz koncentracja towarowa i usługowa eksportu w 2011 i 2019 (2018), mierzona wskaźnikiem HH Share of export of goods and services to the BSR countries in total trade in 2019 (2018 for services) and the goods and service concentration of exports in 2011 and 2019 (2018), measured by the HH index Opracowanie własne na podstawie danych Eurostatu (2020).

komputerowy etc.), choć równolegle wzrastały też udziały np. produktów żywnościowych. Generalnie struktura towarowa handlu wewnątrz makroregionu bałtyckiego jest zbliżona do struktury eksportu do krajów UE-28. Z kolei przedstawienie głównych tendencji w zakresie wymiany towarowej jest o tyle trudne, że oprócz generalnych cech dotyczących modernizacji towarowej eksportu i specjalizacji gospodarek, nie można wykazać wspólnych cech strukturalnych tak złożonego regionu, jakim jest BSR.

Grupa krajów BSR nie jest homogeniczna, jeśli chodzi o specjalizacje eksportowe w zakresie usług. Przeciętnie w krajach BSR znaczenie usług transportowych oraz podróży było w 2018 r. dużo większe niż innych usług (odpowiednio 29,2\% i 25,7\%). Ponadto w strukturze międzynarodowej wymiany usług ważne są również tzw. pozostałe usługi gospodarcze (np. prawne, księgowe, architektoniczne) stanowiące 19,0\% eksportu usług krajów BSR wewnątrz makroregionu oraz usługi telekomunikacyjne, informatyczne i informacyjne (odpowiednio 11,9\%). W porównaniu z 2011 r. zmalało znaczenie usług transportowych (o ponad 5 p.p.), tu niekwestionowanym liderem była Litwa z udziałem BSR na poziomie 59,1\% w obrotach ogółem. Struktury w międzynarodowym handlu usług pomiędzy krajami BSR nie odbiegają znacząco od analogicznych struktur w obrocie z krajami UE-28. Usługi napraw i konserwacji są relatywnie bardziej znaczące dla gospodarki Finlandii (11,0\%), a usługi budowlane w Estonii $(10,0 \%)$, Danii $(9,8 \%)$ oraz na Łotwie $(9,5 \%)$. 


\section{Powiązania towarowe w BSR w ujęciu lokalnym na przykładzie Polski}

Od początku lat 90. XX w. proces integracji Polski z systemem gospodarki światowej oraz równolegle z gospodarką UE oznaczał wzrost zaangażowania w międzynarodowy handel. Kryzys finansowy w 2007 r. jedynie na chwilę spowolnił procesy specjalizacji geograficznej i towarowej tego handlu (por. Komornicki et al., 2015). W 2019 r. w Polsce udział eksportu towarów i usług w PKB wyniósł 55,8\%. Zjawisko to było silnie zróżnicowane przestrzennie. Na wschodzie kraju, na obszarach o bardziej tradycyjnej strukturze gospodarki i generalnie słabszych ekonomicznie, poziom otwartości gospodarki był również najmniejszy.

W badanym okresie kraje UE były głównym odbiorcą towarów z Polski, przy czym ich znaczenie delikatnie wzrosło do poziomu 80,0\% wymiany ogółem. Równocześnie udział krajów BSR nieznacznie zmalał z 42,1\% do 38,4\%. Natomiast udział krajów skandynawskich w eksporcie ogółem towarów z Polski w 2019 r. wyniósł 6,6\% i był zaledwie o 1,0 p.p. niższy niż w 2011 r. Ogólnie w 2019 r. wielkość eksportu do krajów BSR wyniosła blisko 100 miliardów euro (z czego 65,0 mld stanowił eksport do Niemiec, a 15,1 - do krajów skandynawskich).

W latach 2011-2019 dynamika wywozu towarów z Polski do UE-28 wyniosła 151,6 i była tylko nieznacznie wyższa od przyrostu ogółem. Z kolei rynek państw BSR nie był tak atrakcyjny jak rynek unijny ogółem, przeciętnie eksport przyrósł o 35,5\%, na tym tle najmniej konkurencyjny dla firm z Polski okazał się rynek skandynawski (przyrost o 29,1\%). Tym samym w skali całego kraju silniejsze okazały się powiązania towarowe i rynki zbytu w ramach ugrupowania państw europejskich niż w ramach makroregionu bałtyckiego.

Biorąc pod uwagę koncentrację towarową eksportu, wymiana z UE jak i BSR charakteryzuje się wskaźnikiem HH na zbliżonym poziomie (0,2354 w 2019 r.) i nie ulegała dużym przemianom w ostatnich latach. Spadek stopnia koncentracji towarowej eksportu odnotowała jedynie wymiana ogółem (z 0,3581 na 0,2368), osiągając poziom zbliżony do UE i BSR. Co ważne, można również wskazać duże podobieństwo w zakresie eksportowanych towarów do krajów UE, jak i makroregionu bałtyckiego. Do najważniejszych grup towarowych w przypadku obu grup krajów należą maszyny i urządzenia mechaniczne $(21,2 \%)$ oraz pojazdy (wraz z częściami do nich; 16,7\%). Istotnym przedmiotem eksportu pozostają również metale nieszlachetne $(12,5 \%)$, produkty przemysłu chemicznego $(5,4 \%)$ oraz tworzywa sztuczne (8,1\%). W dużym stopniu eksport towarów w obrębie krajów unijnych i BSR dotyczy wymiany wewnątrzgałęziowej. Choć udział artykułów rolno-żywnościowych w handlu międzynarodowym systematycznie maleje, w Polsce w ujęciu dynamicznym w ostatnich latach zyskuje na znaczeniu wywóz produktów żywnościowych do krajów BSR.

Dla Polski od okresu transformacji gospodarczej najważniejszym partnerem handlowym są Niemcy (34,6\% eksportu ogółem w 2019 r.), a ich główna pozycja nie zmienia się od wielu lat. Stąd też badanie roli krajów BSR warto zawęzić do krajów skandynawskich (Dania, Norwegia, Szwecja i Finlandia). Tylko w takim ujęciu możliwe jest zaobserwowanie podstawowych wzorców rozwoju współpracy gospodarczej w ujęciu przestrzennym.

W wymianie handlowej ze Skandynawią specjalizują się powiaty położone na północy kraju. Im bardziej na południe, tym znaczenie tego eksportu jest mniejsze (ryc. 4). Tym samym prawidłowości przestrzenne eksportu towarów do krajów skandynawskich są ściśle powiązane z modelem grawitacji, a konkretnie z odległością i tradycyjnymi powiązanymi gospodarek lokalnych z tymi krajami. Na obszarze województw pomorskiego i zachodniopomorskiego w większości powiatów udział eksportu do krajów skandynawskich znacznie 
przekracza średnią krajową. W powiatach Świnoujście i kamieńskim udział omawianego rynku przekroczył 70\%. Również powiaty z województw warmińsko-mazurskiego, podlaskiego i kujawsko-pomorskiego wyróżniają się pod tym względem. Natomiast rynek ten nie był istotny dla województw południowo-wschodniej Polski.

W ujęciu bezwzględnym największymi obrotami odznaczają się w większości duże miasta: Warszawa, Poznań, Gdynia i Gdańsk (powyżej 400 mln euro), dla których relatywnie rynek skandynawski nie jest tak istotny (poza Gdańskiem i Gdynią - odpowiednio 12,7 oraz 22,3\%).

Na podstawie kształtowania się wskaźnika dynamiki można przypuszczać, że rynek ten będzie zyskiwał na znaczeniu w porównaniu do rynku unijnego. W powiatach o dużym wolumenie wywozu dynamika eksportu do krajów unijnych jest zbliżona do dynamiki eksportu do krajów skandynawskich. Tym samym powiaty te zaczynają doceniać atrakcyjność rynku skandynawskiego (wielkość rynku, bliskość geograficzna, powiązania osobiste), który to staje się konkurencyjny dla rynku unijnego. Obecnie można mówić też o ekspansji przestrzennej wymiany towarowej ze Skandynawią na poziomie lokalnym w Polsce. Największą dynamiką odznaczają się powiaty dotychczas w niewielkim stopniu uczestniczące w tej wymianie. Ten rynek okazuje się być atrakcyjnym rynkiem zbytu dla regionów, które dotychczas nie wykazywały silnych relacji w obrębie BSR, ale z innymi krajami UE - już tak. W latach 2011-2019 zdecydowanie wyższym przyrostem wolumenu eksportu (powyżej 50 p.p.) z krajami skandynawskimi niż z krajami UE-28 charakteryzuje się duża liczba powiatów położonych poza województwami o największym wolumenie wywozu w tym kierunku (ryc. 4).

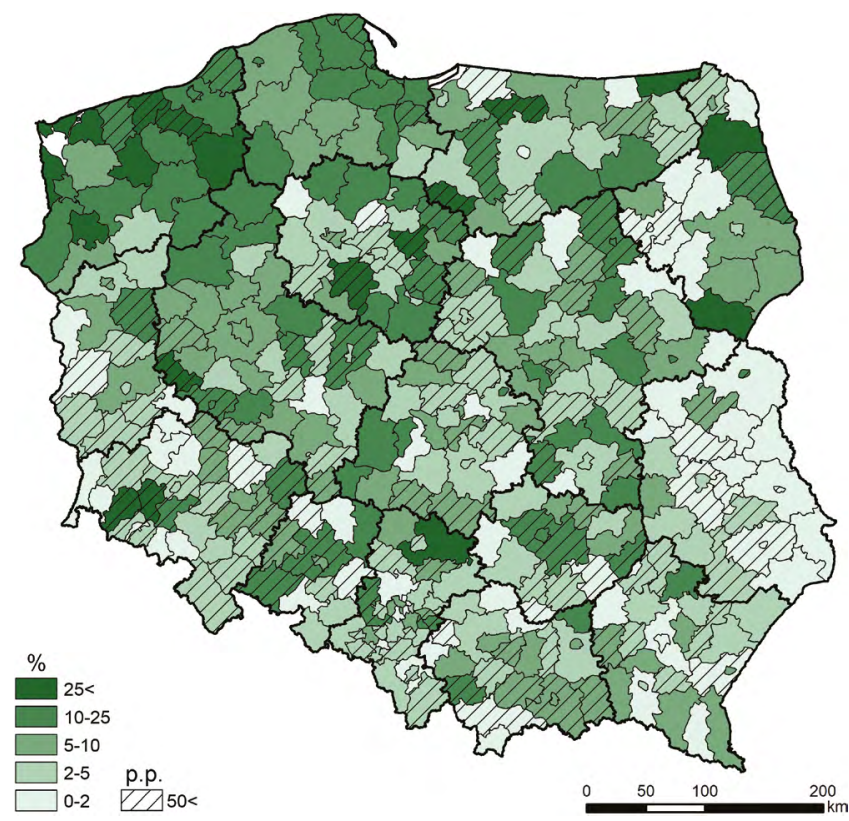

Ryc. 4. Udział eksportu do krajów skandynawskich w eksporcie ogółem w 2019 r. oraz różnica w dynamice eksportu do krajów skandynawskich i UE Share of exports towards the Nordic countries in total exports in 2019 and the difference in the dynamics of exports to the Nordic countries and to the EU Opracowanie własne na podstawie danych Krajowej Administracji Skarbowej. 


\section{Dyskusja i podsumowanie}

W XXI w. na rozwój współpracy w BSR istotny wpływ miały dwa wydarzenia, mianowicie: rozszerzenie UE w 2004 r., dzięki któremu Bałtyk stał się morzem wewnętrznym UE (poza odcinkiem wybrzeża rosyjskiego) oraz opracowanie i wdrożenie w 2009 r. Strategii UE dla regionu Morza Bałtyckiego, która nadała ramy współczesnemu pogłębianiu współpracy krajów nadbałtyckich wewnątrz struktur unijnych (zapoczątkowała też „makroregionalizację" przestrzeni UE). Pierwotnie przyjęty model współpracy skupiał się na kluczowych kwestiach środowiskowych, by następnie rozwinąć się na obszary polityki, w tym transgranicznej (współpraca instytucjonalna), powiązań transportowych i gospodarczych (Palmowski, 2017). Obecnie nadal wiele aspektów związanych z kształtowaniem relacji gospodarczych w BSR, z uwagi na ich złożoność i dynamiczne ujęcie, pozostaje trudnych do uchwycenia. Niniejszy artykuł, wpisując się w nurt współczesnych badań nad BSR jako regionem ekonomicznym, próbuje wypełnić lukę w zakresie skali i intensywności relacji gospodarek BSR.

W ostatnich latach zmiany w powiązaniach handlowych doprowadziły do znaczącego wzrostu wolumenu handlu zagranicznego towarami i międzynarodowego obrotu usług, co potwierdza wstępną tezę o pogłębianiu integracji w BSR. Niemniej jednak proces ten następuje w sposób nierównomierny, jest zdecydowanie silniejszy w przypadku powiązań towarowych, a słabszy w przypadku powiązań usługowych. Warto podkreślić, że w badanym okresie najszybsze tempo wzrostu odnotował właśnie handel usługami. Choć odległość i sąsiedztwo wydają się wyraźnie sprzyjać silnym wzajemnym związkom między krajami położonymi nad Morzem Bałtyckim, jest to też proces nierównomiernie rozłożony w przestrzeni m.in. z uwagi na znaczne różnice w wielkości rynku poszczególnych krajów BSR (istotne w przypadku wymiany handlowej) i historycznie ukształtowane relacje gospodarcze (por. Casillas, 2012; Peschel, 1998). Obecnie największe znaczenie ma handel z krajami BSR dla małych gospodarek krajów bałtyckich, wynika to częściowo z ich tranzytowego położenia pomiędzy Europą Zachodnią a Europą Wschodnią (tudzież Rosją).

Już w 1998 r. Peschel podkreślała, że BSR, uwzględniając wszystkie państwa nadbałtyckie, stanowi skomplikowany obszar o wysokiej integracji gospodarczej. Obecnie na tym obszarze można wyodrębnić podstawowy rdzeń powiązań handlowych pomiędzy krajami skandynawskimi, natomiast Polska (i w mniejszym stopniu Niemcy, które są silniej powiązane z krajami Europy Zachodniej) wykazują tendencje do pogłębiania powiązań handlowych z krajami BSR. W obu przypadkach również sąsiedztwo zdecydowanie przemawia za pogłębianiem wzajemnych relacji. Biorąc pod uwagę zależny od ścieżki charakter procesu eksportowego (przyszłe cele eksportowe zależą w pewnym stopniu od wcześniejszych osiągnięć eksportowych, Casillas, 2012), można zakładać, że w kolejnych latach wymiana towarowa będzie $w$ dalszym ciągu głównym przedmiotem handlu pomiędzy krajami BSR, a wzrost jego wolumenu w zdecydowanej mierze będzie opierał się na dotychczas wypracowanych kierunkach współpracy. Tym samym na znaczeniu zyskuje czynnik dostępności transportowej w BSR, a priorytetowo powinny być traktowane zarówno korytarze paneuropejskie, jak i sieć infrastruktury regionalnej, tj. nie tylko połączenia z metropoliami, ale też z obszarami bezpośrednio przyległymi, w celu wzmacniania potencjału obszarów przygranicznych w BSR (por. BT2050, 2020; Klatt i Winkler, 2020).

Analiza przestrzennego rozwoju wymiany towarowej z krajami skandynawskimi na poziomie lokalnym dowodzi stałej aktualności i popularności modeli grawitacji w badaniu 
prawidłowości związanych z kształtowaniem relacji eksportowych (por. Zwinkels i Beugelsdijk, 2010). Dla gospodarek lokalnych odległość względem rynku zbytu oraz lokalna baza ekonomiczna są istotnymi czynnikami różnicującymi wielkość i znaczenie eksportu do krajów skandynawskich. Podobne prawidłowości w Polsce można zaobserwować również na przykładzie handlu z Niemcami, choć z uwagi na coraz większą skalę wymiany, są one słabsze (Komornicki et al., 2015). Działalność eksportowa na obszarach przygranicznych wskazuje na silniejsze relacje z sąsiednimi krajami. Szejgiec-Kolenda (2018) zauważyła, że na obszarach położonych przy granicach lądowych udział eksportu do krajów sąsiednich był ponad czterokrotnie wyższy niż przeciętnie w kraju, a jak wskazują wyniki niniejszego badania tendencja ta dotyczy również granicy morskiej.

Z kolei Hacker i Einarsson (2003) przetestowali, że model grawitacyjny sprawdza się w przypadku handlu Estonii, Łotwy i Litwy z krajami skandynawskimi. Z drugiej strony, jak pokazują ostatnie badania Brodzickiego i Umińskiego (2017), jeśli główne determinanty handlu zagranicznego wyjaśnia model grawitacyjny i zależność od ścieżki, to w pogłębianiu współpracy z krajami skandynawskimi w ramach integracji z BSR, samo przypisanie do BSR ma drugorzędne znaczenie. Niemniej jednak koncepcja grawitacji ma wiele zalet i może stanowić ważny kierunek analizy intensywności stosunków handlowych w makroregionie BSR.

Makroregionalną strategię UE dla regionu Morza Bałtyckiego można traktować jako nową formę różnicowania integracji w UE, a wypracowane instrumenty polityki i procesu wdrażania strategii - jako odpowiedź na zapotrzebowanie na dedykowaną poszczególnym obszarom o zasięgu ponadnarodowym politykę spójności (Gänzle i Kern, 2016). Ostatnie badania zwracają również uwagę na znaczenie nieformalnych barier w handlu międzynarodowym, spowodowanych czynnikami niematerialnymi. Ramy instytucjonalne są ważnym elementem wyjaśniającym wielkość kosztów transakcji, a odpowiednie zarządzanie publiczne ułatwia handel (de Groot et al., 2004; Li i Samsell, 2009; Wu et al., 2012). Tym samym można przypuszczać, że funkcjonowanie Strategii UE dla Morza Bałtyckiego będzie oddziaływało pozytywnie na przyszły wolumen obrotów handlowych w regionie.

Podsumowując, region BSR jest silnie zróżnicowany wewnętrznie. Dotyczy to aspektów gospodarczych, społecznych i demograficznych (Kubka, 2018). Co więcej, można przypuszczać, że region ten dalej nie będzie regionem homogenicznym (Laaser i Schrader, 2002), również pod względem regionalnych wzorców handlowych. Tym samym powstają pytania odnoście dalszego procesu integracji gospodarczej i specyfiki współpracy w ramach BSR. Jednak jak wskazują Paas i Tafenau (2004) tradycyjnie udane procesy integracji regionalnej mają miejsce między krajami, które są na tym samym poziomie gospodarczym i mają podobne ramy polityczne i instytucjonalne. Potwierdzają oni, że przypadek BSR stanowi wyjątek, ponieważ kraje czerpią korzyści z integracji ze względu na „efekt synergii niejednorodności”. I tak w przeszłości kraje rozwinięte Europy Zachodniej zyskiwały na współpracy gospodarczej z krajami BSR (zwiększony eksport i napływ BIZ, w szczególności przed rozszerzeniem UE w 2004 r.), a obecnie w szczególności kraje bałtyckie i Polska należą to grupy krajów, które w większym stopniu wykorzystują przewagi w handlu z krajami regionu. 


\section{Piśmiennictwo}

Boehe, D.M., \& Jiménez, A. (2016). How does the geographic export diversification - performance relationship vary at different levels of export intensity? International Business Review, 25(6), 1262-1272. https://doi.org/10.1016/j.ibusrev.2016.03.011

Brodzicki, T., \& Umiński, S. (2018). A gravity panel data analysis of foreign trade by regions: the role of metropolises and history. Regional Studies, 52(2), 261-273.

https://doi.org/10.1080/00343404.2017.1296123

BT2050. (2019). Territorial Scenarios for the Baltic Sea Region. Main Report. Pobrane z: https:// www.espon.eu/BT\%202050 (18.05.2020).

Casillas, J.C., Moreno, A.M., \& Acedo, F.J. (2012). Path dependence view of export behaviour: A relationship between static patterns and dynamic configurations. International Business Research, 21(3), 465-479. https://doi.org/10.1016/j.ibusrev.2011.05.008

Castells, M. (1998). The Rise of the Network Society. Malden, Mass: Blackwell.

Cerić, D. (2019). Transgraniczna przestrzeń turystyczna obszarów morskich i nadmorskich na przykładzie Morza Bałtyckiego - próba wyjaśnienia pojęcia. Przeglqd Geograficzny, 91(4), 531-551. https://doi.org/10.7163/PrzG.2019.4.5

Eurostat. (2020). Eurostat Database. Pobrane z: https://ec.europa.eu/eurostat/data/database (30.04.2020).

Faludi, A. (2019). New Horizons: Beyond Territorialism. Europa XXI, 36, 35-44. https://doi.org/10.7163/Eu21.2019.36.3

Fedorov, G.M., \& Mikhaylov, A.S. (2018). Regional divergence dynamics in the Baltic region: Towards polarisation or equalization? Geographia Polonica, 91(4), 399-411.

https://doi.org/10.7163/GPol.0127

Gänzle, S., \& Kern, K. (2016). Macro-regions, 'macroregionalization' and macroregional strategies in the European Union: Towards a new form of European governance? W: S. Gänzle, K. Kern (red.), A macro-regional Europe in the making. Theoretical approaches and empirical evidence (s. 3-22). Basingstoke: Palgrave Macmillan. https://doi.org/10.1007/978-1-137-50972-7_1

de Groot, H.L.F., Linders, G.J., Rietveld, P., \& Subramanian, U. (2004). The Institutional Determinants of Bilateral Trade Patterns. Kyklos, 57(1), 103-124. https://doi.org/10.1111/j.0023-5962.2004.00245.x

Hacker, R.S., \& Einarsson, H. (2003). The pattern, pull, and potential of Baltic Sea trade. Annals of Regional Science, 37, 15-29. https://doi.org/10.1007/s001680200105

KE. (2009). Komunikat Komisji do Parlamentu Europejskiego, Rady, Europejskiego Komitetu Ekonomiczno-Społecznego i Komitetu Regionów dotyczqcy Strategii Unii Europejskiej dla regionu Morza Bałtyckiego. Pobrane z: https://ec.europa.eu/regional_policy/pl/policy/cooperation/ macro-regional-strategies/baltic-sea/ (25.05.2020).

Kebza, M., Nováček, A., \& Popjaková, D. (2019). Socio-Economic disparities in the Baltic States: Analytical comparison and categorization of the regions. Geographia Polonica, 92(3), 289-307. https://doi.org/10.7163/GPol.0150

Klatt, M., \& Winkler, I. (2020). Lessons from the Danish-German Border Region for Post 2020 Interreg A - an Alignment with Cross-Border Functional Regions? Europa XXI, 38.

https://doi.org/10.7163/Eu21.2020.38.5

Komornicki, T., Zaucha, J., Szejgiec, B., \& Wiśniewski, R. (2015). Powiq̨zania eksportowe gospodarki lokalnej w warunkach zmiennej koniunktury - analiza przestrzenna. Warszawa: IGiPZ PAN. 
Konecka-Szydłowska, B., Churski, P., Herodowicz, T., \& Perdał, R. (2019). Europejski kontekst wpływu współczesnych megatrendów na rozwój społeczno-gospodarczy. Ujęcie syntetyczne. Przeglqd Geograficzny, 91(2), 39-59. https://doi.org/10.7163/PrzG.2019.2.3

Kubka, A. (2018). Szwecja i problemy spójności współpracy państw w Europie Bałtyckiej w 2018 roku. Gdańskie Studia Międzynarodowe, 16(1-2), 5-21. https://doi.org/10.5604/01.3001.0012.7622

Laaser, C.F., \& Schrader, K. (2002). European Integration and Changing Trade Patterns: The Case of the Baltic States. Working Paper, 1088. Pobrane z: https://www.econstor.eu/bitstream/10419/2690/1/kap1088.pdf (21.05.2020).

Leszczyna-Rzucidło, M. (2014). Region Morza Bałtyckiego jako modelowy makroregion UE. Gdańskie Studia Międzynarodowe, 12(1-2), 78-90.

Li, S., \& Samsell, D.P. (2009). Why some countries trade more than others: the effect of the governance environment on trade flows. Corporate Governance: An International Review, 17, 47-61. https://doi.org/10.1111/j.1467-8683.2008.00715.x

Misztal, P. (2011). Koncentracja towarowa eksportu a wzrost gospodarczy w krajach Unii Europejskiej. Ekonomista, 5, 691-708.

North, M. (2012). Reinventing the Baltic Sea Region: From the Hansa to the EU-Strategy of 2009. Revista Română de Studii Baltice şi Nordice, 4(2), 5-17.

Paas, T., \& Tafenau, E. (2005). European trade integration in the Baltic Sea Region - A gravity model based analysis. Discussion Paper, 331. Pobrane z: https://www.econstor.eu/bitstream/10419/19299/1/331.pdf (12.05.2020).

Palmowski, T. (2017). Baltic Europe - 40 years of integration. Studia Regionalia, 52, 41-57. https://doi.org/10.12657/studreg-52-03

Perrin, T. (2020). The macro-regionalisation of the western Mediterranean, between renewal and uncompletion. Europa XXI, 38. https://doi.org/10.7163/Eu21.2020.38.3

Peschel, K. (1998). The Baltic Sea Region: An Economically Highly Integrated Area in Future. Discussion Paper, 36. Pobrane z: http://www.geo.ut.ee/nbc/paper/peschel.htm (12.05.2020).

Purju, A., \& Branten, E. (2013). The Economies of the Baltic Sea Region: Growth Patterns and Foreign Trade Now and in the Future. Journal of East-West Business, 19(1-2), 4-15. http://dx.doi.org/10.1080/10669868.2013.779541

Słomczyńska, I. (2014). Strategie makroregionalne Unii Europejskiej jako instrument zarzqdzania wielopoziomowego. Warszawa: Centrum Europejskie Natolin.

Statistik sentralbyrå. (2020). Statistics Norway. Pobrane z: https://www.ssb.no/(20.04.2020).

Stead, D. (2011). Policy and Planning Brief. European Macro-regional Strategies: Indications of Spatial Rescaling? Planning Theory and Practice, 12(1), 163-167. https://doi.org/10.1080/14649357.2011.545664

Szejgiec-Kolenda, B. (2018). Export activity patterns of border regions in Poland. Europa XXI, 34, 113-122. https://doi.org/10.7163/Eu21.2018.34.7

Śmigerska-Belczak, I. (2017). Współpraca międzynarodowa w regionie Morza Bałtyckiego i strategia Unii Europejskiej w tym zakresie. Gdańskie Studia Międzynarodowe, 15(1-2), 27-45.

TE. (2020). TradingEconomics. Pobrane z: https://tradingeconomics.com/(20.04.2020).

Tiits, M. (2006). Industrial and trade dynamics in the Baltic Sea region - the last two waves of European Union enlargement from a historic perspective. Institute of Baltic Studies, Working Paper, 1. Pobrane z: https://www.ibs.ee/wp-content/uploads/Baltic_Sea_Region Marek_Tiits IBS_WP_1_2006.pdf (18.05.2020). 
VASAB. (2010). VASAB Long-Term Perspective for the Territorial Development of the Baltic Sea Region. Pobrane z: https://vasab.org/wp-content/uploads/2018/06/vasab_Itp_final-2.pdf (18.05.2020).

WB. (2020). World Bank Open Data. Pobrane z: https://data.worldbank.org/ (20.04.2020).

WF. (2020). The World Factbook. Washington, DC: CIA.

Wu, J., Li, S., \& Samsell, D. (2012). Why some countries trade more, some trade less, some trade almost nothing: The effect of the governance environment on trade flows. International Business Review, 21(2), 225-238. https://doi.org/10.1016/j.ibusrev.2011.02.007

Zaucha, J. (2007). Rola przestrzeni w ksztattowaniu relacji gospodarczych. Ekonomiczne fundamenty planowania przestrzennego w Europie Battyckiej. Gdańsk: Fundacja Rozwoju Uniwersytetu Gdańskiego.

Zaucha, J., Pyć, D., Böhme, K., Neumann, L., \& Aziewicz, D. (2020). EU macro-regional strategies for the Baltic Sea Region after 2020. A nutshell of beauty and possibilities. Europa XXI, 38. https://doi.org/10.7163/Eu21.2020.38.1

Zwinkels, R.C., \& Beugelsdijk, S. (2010). Gravity equations: Workhorse or Trojan horse in explaining trade and FDI patterns across time and space?. International Business Review, 19(1), 102-115. https://doi.org/10.1016/j.ibusrev.2009.09.001

\section{Summary}

Two events exerted an essential influence on the development of collaboration in the Baltic Sea Region (BSR) in the 21st century, namely: extension of the EU in 2004, due to which Baltic Sea became the inner sea of the EU (except for the Russian coast), and the elaboration and implementation in 2009 of the EU Strategy for the Baltic Sea Region, which established the framework for the contemporary deepening of cooperation among the Baltic states inside the EU structures. The initially adopted model of cooperation concentrated on the key environmental issues, to then get extended towards the policy domain, including the transborder policies (institutional cooperation), as well as transport and economic connections (Palmowski, 2017). The article, while following the stream of the current studies of the BSR as an economic region, tries to fill the gap of complexity and dynamism of development processes, concerning the scale and intensity of mutual economic relations in relation to BSR.

Thus, the article presents the basic aspects, associated with the introduction of the macroregional strategies in the EU and a short description of the economic integration process of the BSR. Analysis is presented of the most important regularities regarding trade exchange between the countries of the BSR, with consideration of the quantitative changes (volume, dynamics), and of the structural ones (specialization of trade in goods and services), as well as the trade linkages at the local level, as seen from the perspective of Polish exports (case study).

International comparisons are based primarily on the economic data on foreign trade in goods and in services. The analysis concentrates on the assessment of the transformations in the years 2011-2019 (for trade in services: 2011-2018), that is - already after the establishment of the Strategy and the period of recession, resulting from the global crisis of 2008. 
In the course of the recent years the changes in the trade linkages considered brought a significant increase in the volume of trade, both concerning goods and services (46.3\%), which confirms the initial proposition of the deepening integration within the BSR. Yet, this process takes place in a spatially uneven manner, and it is significantly stronger for the trade in goods than for the services. Internal trade inside the region accounts for as much as $23.7 \%$ of the total trade of the BSR countries (this share for the EU countries amounting to $60.0 \%$ ). Nowadays, the internal trade with the BSR countries is of the highest importance for the small economies of the Baltic states, which is partly due to their intermediate position between Western Europe and Eastern Europe (including, especially, Russia). The analysis of the spatial development of trade with the Nordic countries at the local level in Poland demonstrates the persistence of the applicability and popularity of the gravity models in the study of regularities, associated with the development of export relations; for the local economies the distance to the sales market and the local economic base are the essential factors, differentiating the magnitude and the significance of exports, in this case - to the Nordic countries.

The macroregional Strategy might be treated as a new form of diversified integration within the EU, while the elaborated instruments of the policy and the strategy implementation process can be seen as the response to the need of the cohesion policy, dedicated to the particular areas of supranational dimensions (Gänzle \& Kern, 2016). Summing up, the BSR is strongly internally differentiated, this statement applying to economic, social and demographic aspects (Kubka, 2018). Moreover, it can be expected that the region will remain a heterogeneous area (Laaser \& Schrader, 2002), also in terms of the regional trade patterns. Thereby, new questions arise, concerning the further process of economic integration and the specificity of cooperation in the framework of the BSR. 